\title{
EFFECT OF HIGH FAT DIET ON BODY WEIGHT, VISCERAL FAT WEIGHT, AND PPARG EXPRESSIONS ON VISCERAL FAT IN MICE
}

\author{
Cantika Putri Melyana ${ }^{1}$, Purwo Sri Rejeki ${ }^{2}$, Sony Wibisono Mudjanarko ${ }^{3}$, Lilik Herawati ${ }^{2}$, Mohammad \\ Anam Al-Arif ${ }^{4}$, \\ ${ }^{1}$ Faculty of Medicine, Universitas Airlangga, Surabaya, Indonesia \\ 2 Department of Physiology and Biochemistry, Faculty of Medicine, Universitas Airlangga, Surabaya, Indonesia \\ ${ }^{3}$ Department of Internal Medicine, Faculty of Medicine, Universitas Airlangga, Surabaya, Indonesia \\ ${ }^{4}$ Department of Animal Husbandry, Faculty of Veterinary Medicine, Universitas Airlangga, Surabaya, Indonesia
}

\section{ABSTRACT}

Obesity becomes a global epidemic nowadays. High fat diet used as alternative therapy for obesity. The optimal composition of high fat diet to reduce body weight is still unknown. This study aimed to determine which composition of high fat diet that can decrease body weight, visceral fat, and PPARG expression of visceral fat. This study was conducted at the Faculty of Veterinary Medicine, Universitas Airlangga, for three months by using randomized post-test only control group design. Fifty male mice, 2-3 months old, 18-30 grams were adapted for one week given standart diet AIN93-M, then mice were divided into five groups, namely $\mathrm{K} 1$ (control group, 12\% fat, 20\% protein, 62\% carbs); K2 (30\% fat, $60 \%$ proteins, $0 \%$ carbs); K3 (45\% fat, $45 \%$ protein, $0 \%$ carbs); K4 (60\% fat, 30\% protein, $0 \%$ carbs); and $\mathrm{K} 5$ (75\% fat, $15 \%$ protein, $0 \%$ carbs). Body weight was measured before and after treatment, then the visceral fat and PPARG expressions were evaluated. Statistical comparisons were performed using Statistical Package for the Social Sciences (SPSS) software. After treatment, there was forty three mice. The body weight and visceral fat weight of the mice with high fat diet was decreased. The most significant changes of the body weight was in $K 4$ with -9,60 $\pm 3,806$ grams reduction. The body weight of mice in K5, slightly increased than K2-K4. This could be caused by the hormesis phenomenon. PPARG expressions decreased in group with high fat diet, but increased in K5. The composition of high fat diet in group $K 4$ was the most optimal to decreased the body weight, visceral fat, and PPARG expressions in mice.

Keywords: high fat diet; mice; obesity; PPARG expressions; visceral fat

\begin{abstract}
ABSTRAK
Obesitas menjadi epidemik global dengan angka kejadian yang terus meningkat. Diet tinggi lemak mulai dikonsumsi sebagai terapi penurunan berat badan, namun komposisi yang optimal belum diketahui. Penelitian ini bertujuan untuk mengetahui komposisi diet yang optimal dalam menurunkan ekspresi PPARG dan lemak visceral dengan menggunakan randomized post test only control group design. Mencit dibagi menjadi 5 kelompok dan diberi perlakuan diet selama 4 minggu. K1, kelompok kontrol diberi diet AIN-93M; K2 (30\% lemak, 60\% protein); K3 (45\% lemak, 45\% protein); K4 (60\% lemak, $30 \%$ protein); dan K5 (75\% lemak, $15 \%$ protein). Berat badan mencit K1 pasca perlakuan mengalami peningkatan dari rerata awal 23,80 $\pm 2,440$ gram menjadi 26,90 \pm 4,886 gram, sedangkan pada K2, K3, K4, dan K5 berat badan mencit mengalami penurunan. Selisih

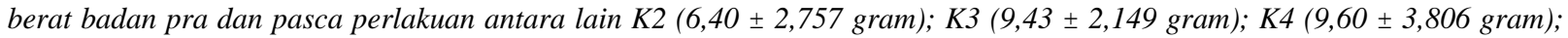
dan $K 5(8,67 \pm 1,862$ gram). Berat lemak visceral maksimal pada K1 $(0,530 \pm 0,088$ gram $)$ dan minimal pada K4 $(0,020 \pm$ 0,063 gram). Ekspresi PPARG maksimal pada K5 (20,83 $\pm 8,308$ per lapang pandang); dan minimal pada K4 (4,90 $\pm 4,900$ per lapang pandang). Komposisi diet tinggi lemak yang optimal menurunkan berat badan, berat lemak visceral, dan ekspresi PPARG yaitu $60 \%$ lemak, $30 \%$ protein, dan $0 \%$ karbohidrat (K4).
\end{abstract}

Kata kunci: diet tinggi lemak; mencit; obesitas; ekspresi PPARG; lemak viseral

Correspondence: Purwo Sri Rejeki, Department of Physiology and Biochemistry, Faculty of Medicine, Universitas Airlangga, Surabaya, Indonesia 60286. Email: purwo-s-r@fk.unair.ac.id; purwo_faal@yahoo.com

pISSN:2355-8393 • eISSN: 2599-056x • doi: 10.20473/fmi.v57i3.16213

- Fol Med Indones. 2021;57:186-191 • Submitted 11 Nov $2019 \bullet$ Received 12 Dec $2019 \bullet$ Accepted 27 Dec 2019

- Open access under CC-BY-NC-SA license $\bullet$ Available at https://e-journal.unair.ac.id/FMI/ 


\section{INTRODUCTION}

Obesity has become global epidemic with the prevalences that keep reported increasing each year in developing country even developed country. This phenomenon caused by the current lifestyles, such as sedentary lifestyle and consuming junk food (Seaman 2013). Obesity has been known as the most common risk factor for several diseases, such as diabetes mellitus, cardiovascular disease, malignancy, infections, and it can bother mental health (Hruby \& Hu 2015). The management or therapy for obesity is complicated, because it needs multifactorial approach to get the optimal results. Most people that spent most of their times seating behind the desk working making the prevention approach become more difficult (Dewitt et al 2019).

Various studies have been conducted to examine the effects produced by the high fat diet as obesity therapy. The accumulation of fat in obese individuals is caused by transcriptional factors peroxisome proliferatoractivated gamma receptor (PPARG) which converts preadipocytes into adipocytes. The application of high fat diet not only succeed in losing weight effectively, but also improved glycemic control, HbAlc, and lipid markers in the body (Paoli 2014). The occurrence of ketosis that exceeds the threshold in individuals who consume the ketogenic diet is proven to cause the mechanism of breaking down adipocytes into ketone bodies and can suppress hunger (Paoli et al 2015, Kirkpatrick et al 2019). Diet monitoring have better chances to become option for the prevention of obesity. People start using high fat diet for the alternative therapy of obesity, but still having a lack acknowledgement about the optimal composition of high fat diet. This study aimed to determine whether or not this high fat diet can decrease body weight, visceral fat weight, and PPARG expressions, and determine which composition have the best result to decrease these variables.

\section{MATERIALS AND METHODS}

Fifty male mice with age 2-3 months old weighing 1830 grams were purchased from Pusat Veterinary Farma, Surabaya, East Java. These mice were divided into five groups with ten mice in each group. Group 1 namely K1 as control group given standard diet with this following compositions, namely $12 \%$ fat, $20 \%$ protein, and $62 \%$ carbs, while group 2 until group 4 were the experimental groups given high fat diet with the following compositions, namely $\mathrm{K} 2$ (30\% fat, $60 \%$ proteins, $0 \%$ carbs); K3 (45\% fat, $45 \%$ protein, $0 \%$ carbs); K4 (60\% fat, $30 \%$ protein, $0 \%$ carbs); and K5
( $75 \%$ fat, $15 \%$ protein, $0 \%$ carbs). All the procedures in this study were approved by the Research Ethics Commissions at the Faculty of Veterinary Medicine with certificate number 2.KE.124.07.2018. Mice were acclimatized for one week to get adapted with the experimental environment in laboratory and given standard diet AIN 93-M. The body weight of mice before the experimental treatment were measured. After the first week, each group was given different diet divided before for 4 weeks.

After the experimental treatment, the remaining mice were weighted the final body weight and euthanized. The mice were firstly anesthetized and the abdomen was incised to get the visceral fat. Then, the visceral fat was weighed and stained with immunohistochemistry techniques using rabbit anti phosphor PPAR Gamma (Series 112) Polyclonal Antibody Unconjugated (Bioss) to see the expression of PPARG antibody. The data of the pre and post experimental body weight, visceral fat weight, and PPARG expression were analyzed statistically. Statistical comparisons were performed by randomized design model by Kruskall Wallis Test and followed by Mann Whitney test using Statistical Package for the Social Sciences (SPSS) software version 16. The analysis used in this study was descriptive and analytic.

\section{RESULTS}

Pre-treatment body weight of the mice were provided in Table 1 . The homogenity variation was scored 0.470 (> $0.05)$ which indicated that the data were homogenous. The normality test resulted $p>0.05$ indicated that the distribution in this data was normal. The $\mathrm{p}$ value from the comparative test was resulted not significantly different.

Table 1. Pre treatment body weight of mice

\begin{tabular}{ccc}
\hline Group & & Pre treatment body weight \\
\cline { 3 - 3 } & & Mean \pm SD \\
\hline 1 & 10 & $23.80 \pm 2.440$ \\
2 & 10 & $25.60 \pm 2.547$ \\
3 & 10 & $24.14 \pm 3.761$ \\
4 & 10 & $23.40 \pm 3.502$ \\
5 & 10 & $25.33 \pm 2.422$ \\
\hline
\end{tabular}

Post treatment body weight can be observed in Table 2 . The result of the homogenity variances test was obtained $p=0.071(>0.05)$. This results indicated that the distribution was normal. Then, the data were analyzed using comparative test and the result that there was a significant different amongst the each post treatment weight group. Groups with $\mathrm{p}$ value $<0,05$ was 
significantly different. Body weight change was the weight difference between pre treatment weight reduced by pre treatment weight that can be observed in Table 2 .

Table 2. Post treatment and Sbody weight of the mice

\begin{tabular}{cccc}
\hline & & $\begin{array}{c}\text { Post treatment body } \\
\text { weight }\end{array}$ & sbody weight \\
\cline { 3 - 4 } Group & $\mathrm{N}$ & Mean $\pm \mathrm{SD}$ & Mean $\pm \mathrm{SD}$ \\
\hline 1 & 10 & $26.90 \pm 4.886$ & $3.50 \pm 2.915$ \\
2 & 10 & $19.20 \pm 3.795$ & $-6.40 \pm 2.757$ \\
3 & 7 & $14.71 \pm 3.729$ & $-9.43 \pm 2.149$ \\
4 & 10 & $13.80 \pm 1.549$ & $-9.60 \pm 3.806$ \\
5 & 6 & $16.67 \pm 2.251$ & $-8.67 \pm 1.862$ \\
\hline
\end{tabular}

The visceral fat from the abdomen were weighed after the mice were dissected. The data of visceral fat weight can be observed in Table 3. From the results of the normality test using the Saphiro Wilk method, the value was mostly $\mathrm{p}<0.05$. This value indicated that in each group, the weight of mice visceral fat had an abnormal distribution. Then, the homogeneity test had resulted $\mathrm{p}$ $<0.05$ which indicated that the data were not homogeneous, so that this visceral fat weight data could be analyzed by Kruskal Wallis comparative test with Mann Whitney advanced test. In the Kruskal Wallis test results, obtained a significance value $\mathrm{p}<0.05$ which indicated that the data were significantly different between each group, so that Mann Whitney advanced test could be performed (Table 4).
Table 3. Visceral fat weight of the mice

\begin{tabular}{ccc}
\hline \multirow{2}{*}{ Group } & $\mathrm{n}$ & Visceral fat weight \\
\cline { 3 - 3 } & & Mean $\pm \mathrm{SD}$ \\
\hline 1 & 10 & $0.530 \pm 0.088$ \\
3 & 10 & $0.090 \pm 0.035$ \\
4 & 7 & $0.057 \pm 0.029$ \\
5 & 10 & $0.020 \pm 0.063$ \\
\hline
\end{tabular}

Table 4. Mann Whitney test results of visceral fat weight

\begin{tabular}{cccccc}
\hline Group & K1 & K2 & K3 & K4 & K5 \\
\hline K1 & & 0.001 & 0.002 & 0.000 & 0.009 \\
K2 & 0.001 & & 0.594 & 0.068 & 0.730 \\
K3 & 0.002 & 0.594 & & 0.168 & 0.357 \\
K4 & 0.000 & 0.068 & 0.168 & & 0.034 \\
K5 & 0.009 & 0.730 & 0.357 & 0.034 & \\
\hline
\end{tabular}

From the visceral fat that stained using immunohistochemistry method, the PPARG expressions can be observed in Figure 1. From the figure can be observed that the PPARG results at each group display different expressions. The data of the PPARG expressions can be seen in Table 5.

Table 5. The PPARG expressions in visceral fat of the mice

\begin{tabular}{ccc}
\hline Group & & PPARG expressions \\
\cline { 3 - 3 } & & Mean \pm SD \\
\hline 1 & 10 & $20.20 \pm 3.306$ \\
2 & 10 & $15.60 \pm 5.470$ \\
3 & 7 & $5.29 \pm 5.286$ \\
4 & 10 & $4.90 \pm 4.900$ \\
5 & 6 & $20.83 \pm 8.308$ \\
\hline
\end{tabular}



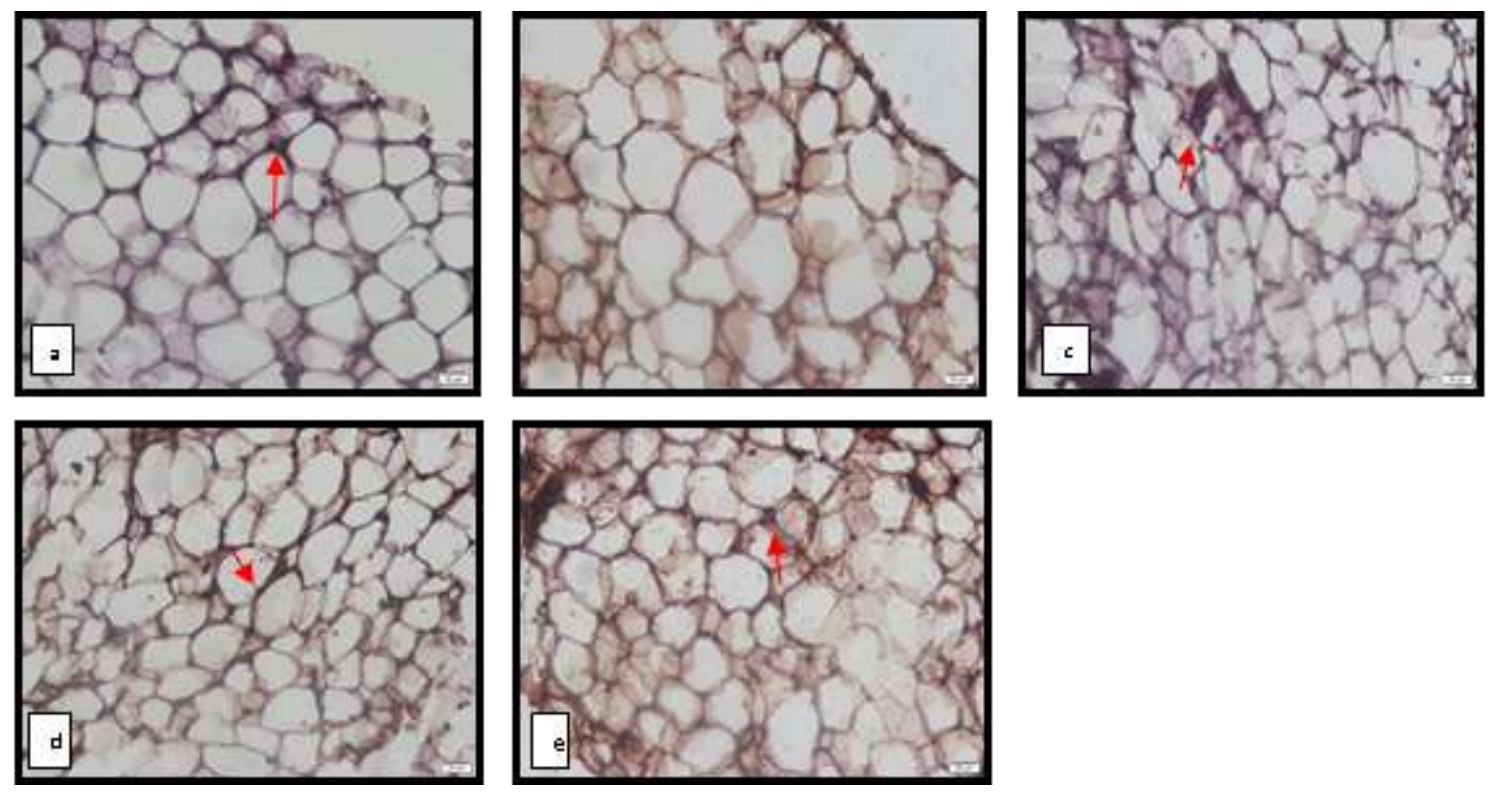

Figure 1. The visceral fat stained with immunohistochemistry showed PPARG expression; (a) K1; (b) K2; (c) K3; (d) K4; (e) K5. The red arrow showed the positive expressions of PPARG

The results of the normality test were found to be more dominant in the value of $\mathrm{p}<0.05$. This value indicated that in each group, the weight of mice visceral fat had an abnormal distribution. Then, the homogeneity test resulted $p>0.05$ and indicated that the data were homogeneous. The non-parametric comparative test with the Kruskal Wallis method was also conducted and obtained a significance value of $\mathrm{p}<0.05$ which indicated that PPARG expression data had significant differences among groups (Table 6). From the results of the Mann Whitney test, it could be observed that groups correlation with $\mathrm{p}$ value $<0,05$ were significantly different.

Table 6. Mann Whitney test result of PPARG expressions in visceral fat

\begin{tabular}{cccccc}
\hline Group & K1 & K2 & K3 & K4 & K5 \\
\hline K1 & & 0.567 & 0.009 & 0.002 & 0.828 \\
K2 & 0.567 & & 0.170 & 0.103 & 0.650 \\
K3 & 0.009 & 0.170 & & 0.862 & 0.103 \\
K4 & 0.002 & 0.103 & 0.862 & & 0.035 \\
K5 & 0.828 & 0.650 & 0.103 & 0.035 & \\
\hline
\end{tabular}

\section{DISCUSSION}

The body weight of mice before treatment was chosen according to the ideal body weight of adult male mice, valued 18-30 grams. From the statistical tests, it was ensured that there were no significant initial weight differences between the control group and the treatment group. After the diet, the treatment was given for 4 weeks according to each group; the data of posttreatment weight were obtained. Then, through the difference in pre and post treatment weight could be analyzed as the result of the effect of the high fat diet that was given on each group. Statistics results on changes in body weight pre and post treatment had a significant difference $(p<0.05)$ which indicated that there was a correlation between the treatment of the high fat diet with the changes of body weight of mice as similar to the study of Heisel et al (2017). Mice in K1 that were the control group, gained weight accordingly to those predicted by control diet treatment using AIN93M which was not low in carbohydrates and mild fat, whereas on $\mathrm{K} 2$ to $\mathrm{K} 5$ that were the experimental treatment group, body weight of the mice experienced a significant decrease compared to body weight before treatment. This was in line with a study that mice with ketogenic diet treatment decreased significant weight (Zhang et al 2018).

The high fat diet given to the $\mathrm{K} 2$ to $\mathrm{K} 5$ had a composition of low carbohydrate and high fat. This diet caused glucose levels in blood was highly low, thus inducing the occurrence of gluconeogenesis and cytogenesis which caused the formation of ketone bodies (Paoli et al 2013). High levels of fat also caused the formation of cholecystokinin stimulated satiety longer, so that the appetite of mice was suppressed, and impacted on the intake consumed by mice became less (Narayanaswami \& Dwoskin 2017). 
The group with the most significant weight loss was found in $\mathrm{K} 4$ with a composition of $0 \%$ carbohydrates, $60 \%$ fat, $30 \%$ protein, and $10 \%$ fiber. Visible tendency for weight loss was increasing from $\mathrm{K} 2$ to $\mathrm{K} 4$, but in $\mathrm{K} 5$ the weight loss was slightly lower than that previous group. This mechanism was thought to be a result of the effects of hormesis in the physiology of mice, which was caused of exposure to the ketogenic diet with fat composition that was too high, body weight of mice did not decrease optimally. Hormesis effect was where the adaptive response biological systems towards exposure received from the environment cause tolerance of more severe challenges (Calabrese \& Mattson 2017).

On a low carbohydrate and high fat diet, the body tend to degrade visceral fat firstly, then followed by subcutaneous fat stimulated by sympathetic nerve pathways. Coinciding sympathetic nerve activity, the visceral fat tissue decreased, and caused weight loss reached the plateau, active sympathetic nerve stimulus towards fat subcutaneous indicating that changes in lipolytic sources had changed (Sipe et al 2017). In the group of mice treated with a high fat diet, visceral fat in the body of mice had been degraded. Even in some groups of mice to visceral fat, these were completely discharged and could not be taken during post-surgery treatment. Visceral fat of mice was obtained from surgery in the abdomen mice and were then weighed using visceral fat microgram scales. Of 43 mice from all groups, only as many as 23 mice had visceral fat in the abdomen at the end of the experiment.

The K1 control group had a higher mean of visceral fat weight compared to groups $\mathrm{K} 2$ to $\mathrm{K} 5$ who received high fat diet. From the statistical analysis, there were significant differences on visceral fat weight among groups ( $p<0.05)$ which indicated that there was a correlation between the administration of the high fat diet with the visceral fat weight in mice as similar to the results of the study of Watanabe et al (2021). These results were in line with the results of a study by Sipe et al (2017), who gained a significant reduction in visceral fat by treatment low calorie diet. The same results in line with the reduction in total fat mass, especially visceral fat on the administration of a low-calorie ketogenic diet to obese patients (Castro et al 2018).

PPARG expression in mice visceral fat was seen using immunohistochemistry staining under a microscope with 400 times magnification as many as 5 visual fields per sample. The PPARG expression was seen, because PPARG had an important role in the process of adipogenesis. In $\mathrm{K} 1$, the highest PPARG expression results were obtained. This matter as expected, where in the given control group AIN-93M standard diet did not get any emphasis on the process of adipogenesis
(Motawi et al 2017). This was also supported by two previous variables, namely body weight and weight of visceral fat of mice that did not decrease before and after treatment.

The tendency of PPARG expression in $\mathrm{K} 1$ to $\mathrm{K} 4$ was experienced a decrease, while reaching K5 with the composition of the ketogenic diet was $0 \%$ carbohydrates, $75 \%$ fat, $25 \%$ protein, and $10 \%$ fiber, PPARG expression slightly increased. This could also be related to the hormesis phenomenon in physiology of the body, which when mice continued to be exposed to diet with a relatively high fat content, deep lipolysis the body would stop and fat would be deposited back in the body (Calabrese \& Mattson 2017). Therefore, PPARG's expression that had slightly increased again. The PPARG expression results were the opposite of the results of a similar study by Zhang et al (2018) who got increased PPARG expression in the treatment ketogenic diet. This was probably due to this study, where PPARG expression was seen by immunohistochemically techniques in visceral fat, whereas in the study of Zhang et al (2018), PPARG expression was seen in protein level using the Western Blot technique.

\section{CONCLUSION}

High fat diet could decrease body weight, visceral fat weight, and PPARG expressions on visceral fat in mice with the most significant reduction in group $\mathrm{K} 4$ that gave high fat diet with the following composition, namely $60 \%$ fat, $30 \%$ protein, and $0 \%$ carbs.

\section{REFERENCES}

Calabrese EJ, Mattson MP (2017). How does hormesis impact biology: Toxicology, and medicine? NPJ Aging Mech Dis 3, 1-8.

Castro AI, Arbelaez DG, Crujeiras AB, et al (2018). Effect of a very low-calorie ketogenic diet on food and alcohol cravings, physical and sexual activity, sleep disturbances, and quality of life in obese patient. Nutrients 10, 1-19.

Dewitt S, Hall J, Smith L, et al (2019). Office workers' experiences of attempts to reduce sitting-time: An exploratory, mixed-methods uncontrolled intervention pilot study. BMC Public Health 19, 1-10.

Heisel T, Montassier E, Johnson A, et al (2017). Highfat diet changes fungal microbiomes and interkingdom relationships in the murine gut. Host-Microbe Biology 2, e00351-17.

Hruby A, Hu F (2015). The epidemiology of obesity: A big picture. Pharmacoeconomics 33, 673-689. 
Kirkpatrick CF, Bolick JP, Kris-Etherton, et al (2019). Review of current evidence and clinical recommendations on the effects of low-carbohydrate and very-low-carbohydrate (including ketogenic) diets for the management of body weight and other cardiometabolic risk factors: A scientific statement from the National Lipid Association Nutrition and Lifestyle Task Force. Journal of Clinical Lipidology 13, 689-711.

Motawi TK, Shaker OG, Ismail MF, et al (2017). Peroxisome proliferator-activated receptor gamma in obesity and colorectal cancer: The role of epigenetics. Scientific Reports 7, 1-8.

Narayanaswami V, Dwoskin LP (2017). Obesity: Current and potential pharmacotherapeutics and targets. Pharmacol Ther 170, 116-147.

Paoli A (2014). Ketogenic diet for obesity: Friend or foe?. International Journal of Environmental Research and Public Health 11, 2092-2107.

Paoli A, Bosco G, Camporesi EM, et al (2015). Ketosis, ketogenic diet and food intake control: a complex relationship. Front Psychol 6, 1-9.
Paoli A, Rubini A, Volek J, et al (2013). Beyond weight loss: A review of the therapeutic uses of very-lowcarbohydrate (ketogenic) diets. European Journal of Clinical Nutrition 67, 789-796.

Seaman D (2013). Weight gain as a consequence of living a modern lifestyle: A discussion of barriers to effective weight control and how to overcome them. Journal of Chiropractic Humanities 20, 27-35.

Sipe LM, Yang C, Ephrem J, et al (2017). Differential sympathetic outflow to adipose depots is required for visceral fat loss in response to calorie restriction. Nutrition \& Diabetes 7, 1-8.

Watanabe R, Yamaguchi M, Watanabe K, et al (2021). Effects of collagen peptide administration on visceral fat content in high-fat diet-induced obese mice. J Nutr Sci Vitaminol 67, 57-62.

Zhang Q, Xu L, Xia J, et al (2018). Treatment of diabetic mice with a combination of ketogenic diet and aerobic exercise via modulations of PPARs gene programs. PPAR Research 2018, 1-13. 